\title{
高精細液晶ディスプレイ実装システムの開発（第2報）* \\ 一液晶駆動ICボンディングッールの熱解析一
}

\author{
玉 井光 - ** 久保田敏春 ${ }^{* * *}$ 太田 誠 ${ }^{\dagger}$
}

Development of High-Definition Liquid Crystal Display Mounting System (2nd Report)

- Thermal Analysis of Bonding Tool for Liquid-Crystal Drive IC's -

Koichi TAMAI, Toshiharu KUBOTA and Makoto OTA

For higher definition and lower cost liquid crystal display, improvement of the mounting accuracy and productivity of liquid crystal driver IC in TCP (Tape Carrier Package) is essential.

In order to mount several TCP's, which previously have been mounted one by one, at one time, temperature-homogenous long bonding tool is needed. The FEM (Finite Element Method) has been used until now for the thermal analysis of the long bonding tool. However, there was a big difference between an analytical and measured values. In order to solve this problem, an FVM (Finite Volume Method) is used, in which ambient air flow and thermal effects on adjacent parts are taken into consideration for heat and flow analysis, for leading to temperature-homogenous of bonding tool.

Key words: Liquid crystal displays, TCP bonding system, Thermal analysis, bonding tool, Finite volume method

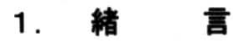

液晶ディスプレイは, 従来のパソコン主体から携帯電話用お よびCRT 代替を目指したテレビ用と多様化している.これらの 用途拡大は, 液晶ディスプレイが高精細化・低価格化さらに大 型化が可能になってきた背景がある. 特に低価格化は重要で, 液晶ディスプレイが今後のフラット・パネル・ディスプレイの 主流になるかは，この低価格化が大きな判断基準となる.

液晶ディスプレイの低価格化は，画素を製造する薄膜工程の PEP(Photo Engraving Process:写真蝕刻工程) 数を堿らし, 工数を 削减することである. さらに実装工程では, 高密度化した画素 の出力端子とフィルム状の液晶駆動 IC ${ }^{1}$ (以降 TCP:Tape Carrier Package）を高速に実装2) し, 生産性を向上させることである. 本論文は, 後者の TCP 実装工程の生産性向上を対象としている.

図 1 に TCP を実装した液晶ディスプレイを図 2 に TCP 接続 部の拡大写真を示す.

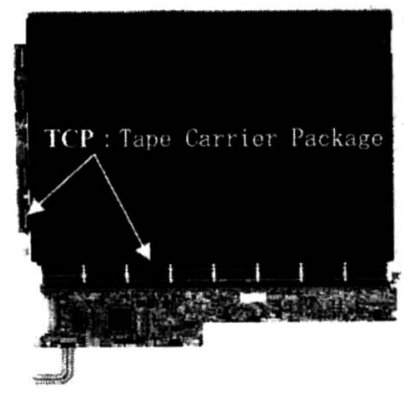

Fig.1 Liquid crystal display with TCP's mounted

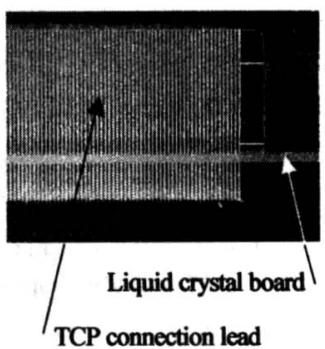

Fig.2 Enlarged picture of TCP connection
液晶基板への TCP 実装は, その間に異方性導電膜 ${ }^{3}$ ）（以降 ACF : Anisotropic Conductive Film) を介して行う. ACF は, 厚

* 原稿受付 平成 13 年 3 月 22 日

** 正 会 員 梀東芝 生産技術センター（横浜市磯子区新磯子 33）

*** 社東芝 電力シス京都府中市東芝町)

† 芝浦メカトロニクス株（海老名市東柏ヶ谷 5-14-1）
さ $15 \mu \mathrm{m}$ の接着剤層中に粒径 $5 \mu \mathrm{m}$ の導電性粒子を均一な分布 で混入させたものである. TCP〜ACF〜液晶基板を加熱・加圧 することにより, 上下間に導電性粒子を介して電気的接続を得 る. 一方, 水平方向には接着剂層によって絶縁性が保たれる.

図 3 に ACF の接続原理, 図 4 に接続部の SEM 画像を示す.

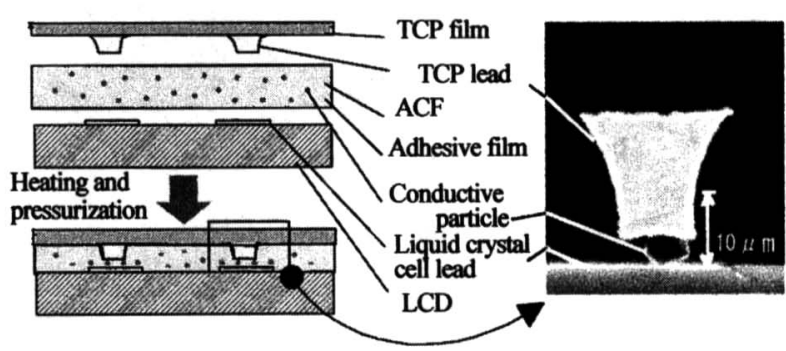

Fig. 3 ACF connection theory

Fig.4 Cross sectional SEM photograph of ACF connection

ACF を使用し， TCP を実装する方式を $\mathrm{TAB}^{4)}$ 方式 (Tape Automated Bonding) と呼称した.

図 5 に TAB 方式の工程図 ${ }^{5)}$ を示す. まず, 液晶基板の電極 部に ACF を圧着する. この際, ACF は自身の接着力で保持固 定する. これを ACF 貼付け工程と呼称した.

ACF を圧着後, TCP と液晶基板の接続リードを光学装置で位 置認識し,ずれを補正した後, TCPを液晶基板一位置決めする. この際, ACF が完全に硬化しない状態の熱と力で TCP を液晶 基板に仮固定する. ACF の接着剂が硬化していない段階のこの 仮固定を仮圧着と呼称した.

$\mathrm{TCP}$ と液晶基板を仮圧着後, 別工程で TCP の上から平坦度を 有するボンディングツールで加熱・加圧し, 本圧着する. 本圧 着の呼称は, TCP と液晶基板の位置関係をずらすことなく, 接 着剂を硬化させることを意味する. 夫々の工程を仮圧着工程, 本圧着工程と呼称した. TCP を位置決め, 熱圧着する仮圧着工 程と本圧着工程を 2 工程に分けた理由は, ACF の接着剤を硬化 させる本圧着工程の生産性が著しく悪いためである. 


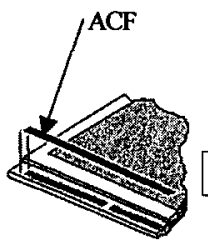

ACF pasted

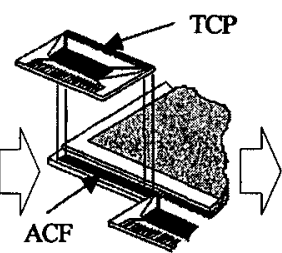

TCP temporarily crimped

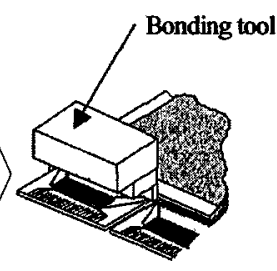

TCP finally crimped

Fig5 Process diagram of TCP mounting

TCP 本圧着工程の生産性を向上させるためには，複数枚ある TCP を一度に一括で実装する必要がある.この実現には TCP 本压着装置のボンディングツールの長尺化が必要であり，その ためにはボンディングツールの温度の均一化が技術課題となる.

従来, このボンディングツールの長尺化が困難なため, TCP は一枚ずつ本圧着していた，ボンディングツールの長尺化がで きなかった理由は，温度の均一化がボンディングッールの長さ で約 $50 \mathrm{~mm}$ 程度が限界であったためである. このため, 生産性 が著しく悪く, 仮圧着装置 ${ }^{6)} 1$ 台に対して 4 5 台の本圧着装置 7) を必要としており，設備投資効率も悪かった。

第 1 報で，26インチの液晶ディスプレイの TCPを一度に一 括で実装できる有効長 $520 \mathrm{~mm}$ の長尺ボンディングッールを具 現化した開発経緯を述べた，これにより，TCP 本圧着工程の生 産性は, “従来に比較し 5.5 倍向上し, 液晶ディスプレイの低価 格化に寄与した。

図 6 に TCP を本圧着する際の従来技術との比較図を示す.

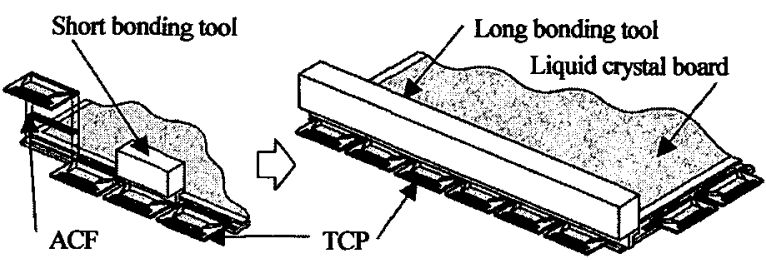

Fig.6 Comparison of bonding tools

\section{2. 開発意}

第 1 報で TCP 本圧着工程のボンディングツールの長尺化を 具現化した機構開発とその熱解析技術を述べた．大幅な生産性 向上を達成したが，開発途上で改善す心゙き点もあった。

それは，熱解析データと測定データの承離である，従来，有 限要素法 FEM（Finite Element Method）による熱伝導を主体と した熱解析を実施した. 熱解析データと測定データで温度プロ ファイルは近似していたが, 温度の絶対值で $8^{\circ} \mathrm{C}$ 乘離があっ た.この非離は，温度のばらつきを補正する際の放熱フィンの 熱容量および取付け場所を調整する余分な工程が発生していた。

図 7 に従来のボンディングツールの FEM による熱解析デー タと測定データを示す。さらに温度の均一性を向上させるため に付設した放熱フィンの取付け位置も示す。

熱解析データと測定データで我離を生じた要因は, FEMによ る熱解析の対象が，ヒータブロックとボンディングッールのみ で，隣接部品への熱伝導や放射伝熱を考慮していないためであ る.

ボンディングツールの温度のばらつきを,さらに小さくする ため，高温な部分に放熱フィンを設置した。これにより，温度 のばらつきは $3.9^{\circ} \mathrm{Cまで、小さくすることができたが，このよ}$ うな放熱フィンによる調整工程が発生していた。

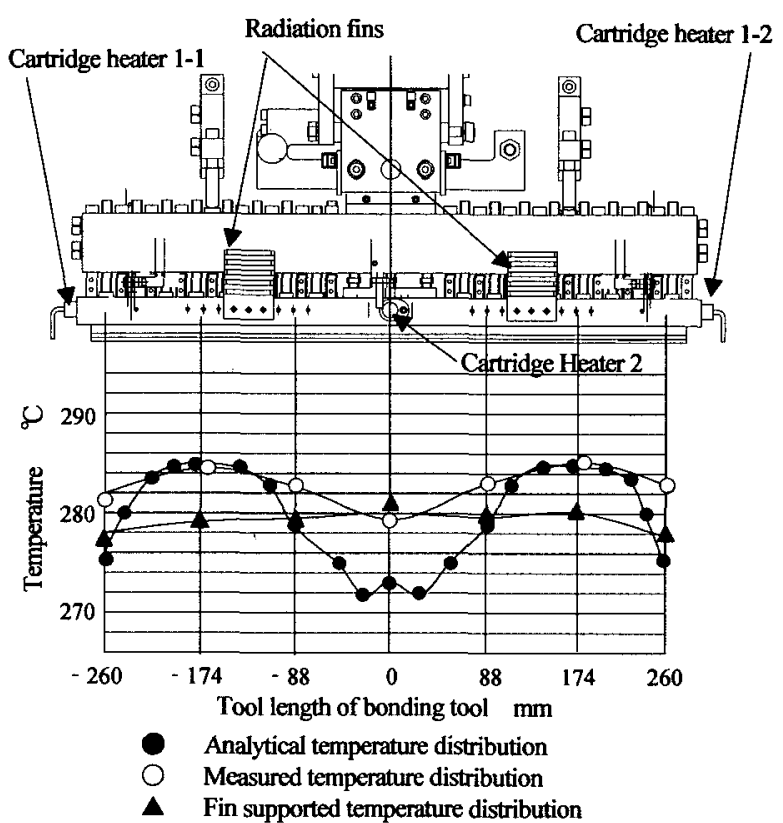

Fig.7 Analytical and measured temperatures around the tip of bonding tool

本閒発の意義は 2 件である. 1 件目は，ボンディングッール の温度の均一化を図るための放熱フィンによる調整工程を排除 することである.このためには, カートリッジヒータのレイア ウトを含めた機構の見直しが必要である.

2 件目は, 設計段階でボンディングツールの温度の均一性を 同定できるようにし，設計・製作のやり直しを排除することで ある.このためには，従来の FEM では解析できない隣接部品 への放射伝熱や架気の対流熱伝達を解析する手法を椿築し，熱 解析の精度を向上させることである.

\section{3. 装 置 㭗 造}

$\mathrm{TCP}$ 本圧着装置は，ACF を接合部材として TCP を液晶基板 に熱圧着する装置である. 生産性の向上を図るため, 液晶ディ スプレイの一辺分の TCP を一度に一括で本圧着するボンディ ングツールを搭載している．図 8 に長尺ボンディングッールを 搭載した TCP 本圧着装置の構造図を示す。

従来の TCP 本圧着装置と異なる点はボンディングツールで ある. 従来のボンディングツールは, 図7に示すようにヒータ ブロックの長手方向で左右から 2 本, 中心に 1 本の計 3 本の力 ートリッジヒータで加熱制御していた．今回はカートリッジヒ 一タをヒータブロックに対して上下方向に複数本挿入した。

ボンディングツール先端は，約 $300^{\circ} \mathrm{C}$ ま加熱するため，ボ ンディングツールの上部には平坦度を出す平坦度調整機構があ る. ボンディングッールは, ツール固定ブロックに複数本のね じで固定している、ツール固定ブロック上のねじは，ボンディ ングッールを固定するねじと平坦度を調整するねじの2 種類を 交互に配設している.このねじの押し引きにより，ボンディン グツール先端の平坦度調整を行っている.

ヒータブロックとボンディングツールは，上下ステージの上 に保持しており，ボールネジで上下に移動する，ボールネジに した理由は，TCP〜ACF〜液晶基板の位置ずれを発生させない ため，ボンディングツールが TCP に接触する瞬閒は，緩やかな 速度になるように速度制御するためである．加圧はボールネジ 上部に取付けたシリンダで行い，その圧力を制御することによ り, ボンディング荷重を変化させる. 
ボンディングツールの下部には，液晶基板とボンディング荷 重を支えるためのバックアップッールがある．液晶基板の裏面 を支えると同時に補助加热するため，バックアップツールにも カートリッジヒータを装填してある.

ボンディングッールおよびバックアップツールは, その材質 が析出硬化型耐食ステンレス銅で, $\mathrm{H}_{\mathrm{R}} \mathrm{C} 40$ 以上の焼入れを行い， 傷がつかないように硬度を上げている. ボンディングツールお よびバックアップツールに傷が入ると,その部分に TCP 接続不 良が発生するためである. ボンディングツールの先端およびバ ックアップッールの先端は, JIS の中心線平均あらさ Ra で 0.2 $\mu$ m以下の加工精度に仕上げた.

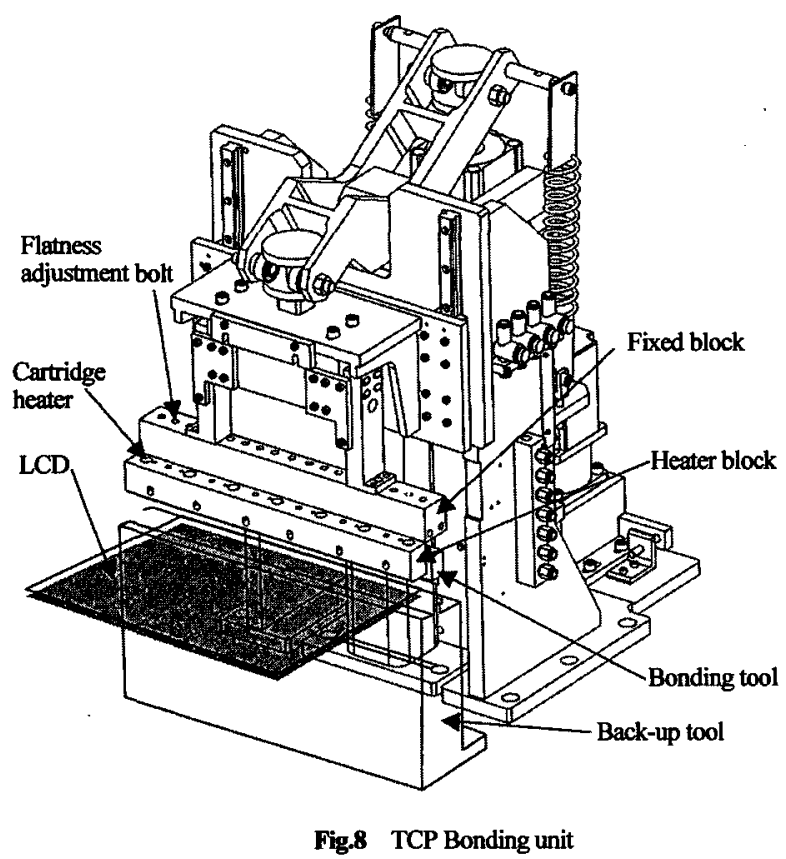

4. 㛙解析の手順と結果

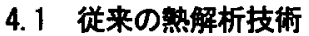

従来の熱解析では, ボンディングツール部のみを取り出して, FEMによる熱伝導・熱応力解析を行った. ボンディングツール の平坦度を調整するねじなどの隣接部品への熱伝導と放射伀熱 は考慮されていない，さらに，表面から空気への対流熱层達は 簡略計算で求めて与えているが, 空気の流れを解析していない. このために，限定された状況での解析であり，精度は必ずしも 十分ではなく, 熱解析デー夕と測定データの比較評価を行って, 相違を踏まえた上で熱解析デーダを適用する必要があった。

\section{2 熱解析の精度向上}

第 1 報の FEM による熱伝導・熱応力解析は，解析対象とな る領域をメッシュ分割し，節点と要素を生成する．その後，境 界条件を与えるが, 熱伝導解析では要素の発熱量または温度を 加えて空気と接する要素の面には, 別途手計算で求めた熱伝達 率を加える. 対称モデルでは対称面に断熱の条件を与える. 熱 応力解析による熱変形を求めるときには，境界条件として対称 面に変位拘束条件を与える. 熱応力解析では熱伝導解析で求め た各節点の温度を引用する. この熱伝導・熱応力解析では, 周 囲の空気の流れと放射伝熱を解析に入れることは困難であった。

これを解決したのが, 有限体積法FVM (Finite Volume Method) による熱・流れ解析である.

この解析手段は，隣接部品を解析モデルに含めることが可能 である. 熱伝導だけではなく，周囲の空気の流れも解析するこ
とで流れに即した対流熱伝達も盛り込み，さらに放射伝熱も解 析の対象にした．高温の場合，放射伝熱が解析結果と実際の测 定值で大きな相違があり，放射伝熱を無視できないことも確認 した.

\section{3 ボンディングッール周辺の熱解析のモデル化}

開発対象の TCP 本圧着装置について, 熱・流九解析を適用し た. 図 9 はボンディンダツール，ヒータブロックとッール固定 ブロックと，さらにはボンディングッールの平坦度を調整する 平坦度調整機構も含めた解析モデルを示す.

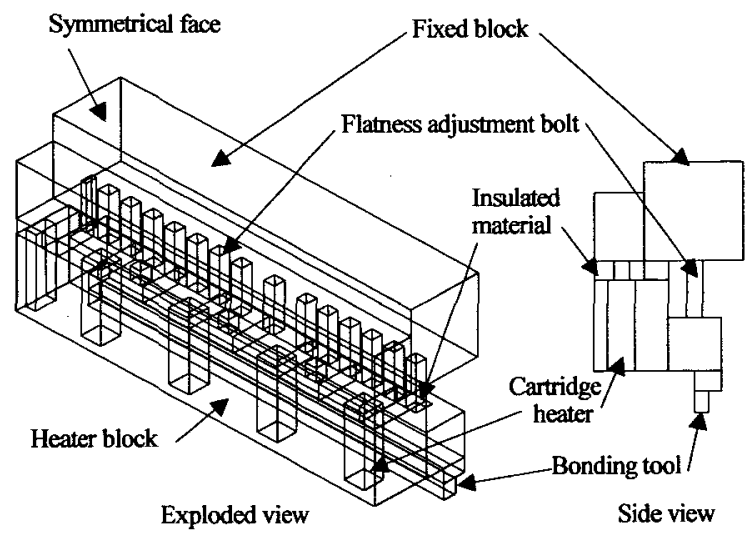

Fig.9 Analytical model of heat and flow around bonding tool

解析対象は左右対称なので, 解析モデルは中心から半分とし た. カートリッジヒータは，上下方向の配置で合計 9 本（解析 モデルでは 4.5 本) である. 実際の装置では, カートリッジヒ 一夕付近に埋め込んだ熱電対で温度を測定して，一定温度にな るようにヒータを ON-OFF 制御した。

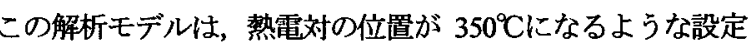
した，各部品にはそれぞれの材料の熱伝導率を与え，解析モデ ルの対称面は断熱の条件を与えた. 周囲の空気の流れも解くた めに，解析領域にはボンディングツール周辺の空気も含まれて いる. ボンディングツールと空気の境界部分は, 空気が自由に 出入りできる条件を与えた. 上下方向の下向きに重力加速度が 加わり，ヒ一タの発熱により周りの空気の温度が上昇して, 密 度差と重力加速度により，自然対流が発生する. 空気の流れを 解析することで，発䓡部分の流速を求めて対流による熱伝達率 を計算する.

各部品の表面からは放射による熱伝達があり，各部品間の形 態保数と, 各部品間および解析領域境界の放射伝熱の夫々を計 算する. 放射率 ${ }^{8)}$ は指定するのであるが, 表面状態によって異 なり金属の光沢面では 0.1 程度であるが, ヒータブロック周辺 では，高温度になるので酸化されて 0.6 0.8 程度になる.

以上の解析モデルからメッシュ分割を行って解析する. 第 1 報で述べた熱伝導解析では，熱伝導する固体領城のみが解析領 域である.これに対して熱・流れ解析の場合は, 周囲の空閒領 域も解析対象になるため，流九の部分はメッシュを細かくする 必要がある.メッシュ数は格段に増大し, 図9の場合でメッシ 二数は約 50,000 となる. また, 変数も熱伝導解析では温度だけ であるのに対して，熱・流九解析では温度と X,Y,Z方向の速度 と圧力の 5 変数に増える. 熱・流れ解析は精度の向上が見込ま れるが計算量としては大幅に多くなる.

図 10 は, ヒータ本数が 9 本の場合の解析結果で, ボンディン グヘッド正面と側面の温度分布を示す. 正面の断面位置は側面 の平坦度調整ねじの中心位置を表したものである. 

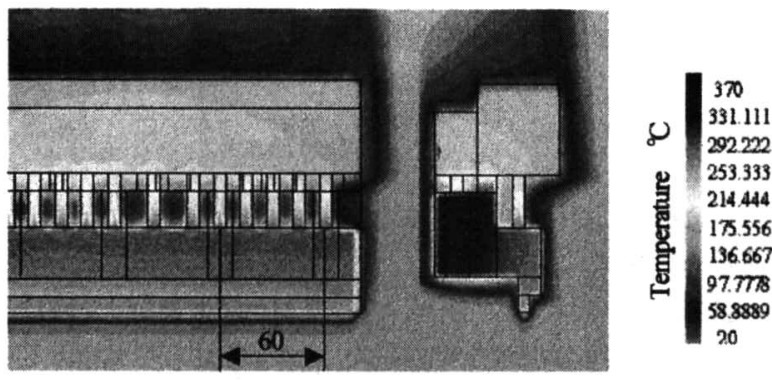

Fig.10 Temperature distribution on front and side faces of bonding head with nine heaters

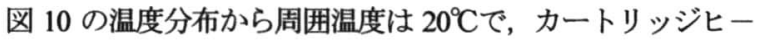
夕の部分が最も温度が高く $370^{\circ} \mathrm{C}$ となっている. TCP を実装す

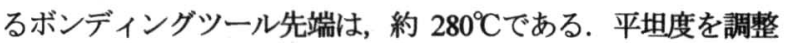
するねじを通して熱伝導があるため, カートリッジヒータから 離れた固定ブロックでも約 $170^{\circ} \mathrm{C}$ 温度となっている. 固定ブ ロックの放射も考慮すると，固定ブロックや平坦度を調整する ねじは，解析上，無視できないことがわかる.

なお, 図 10 の温度分布は, おおまかな温度を掴むもので, 温 度の絶対値は座標指定と計算で，その部分の值を得る.

ボンディングツール先端の各部の温度は, 設定温度 $280^{\circ} \mathrm{C} に$ 対して仕様值の $\pm 5^{\circ} \mathrm{C}$ 以内に収まっていた. この仕様值 $\pm 5^{\circ} \mathrm{C}$ ACF が安定して硬化する温度の許容範囲で第 1 報に詳述した.

この解析モデルはカートリッジヒータの本数が全体で 9 本で あるが, ボンディングツール先端の温度のバラツキは小さいた め, 本数を堿らせることが予測される. さらに本数を 2 本堿ら して解析を行ったところボンディングツール先端の温度のばら

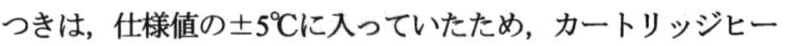
夕は7 本に決定した. 解析後, 実験機を製作し, 温度のばらつ きを測定したところ, ボンディングッールの長手方向でレンジ $4.0^{\circ} \mathrm{C}$ であった. このように設計段階で, 必要最低限のカートリ ッジヒータの本数を同定することが可能となった. 図 11 にヒー タ 9 本を 7 本にした熱・流れ解析結果の温度分布を示す.
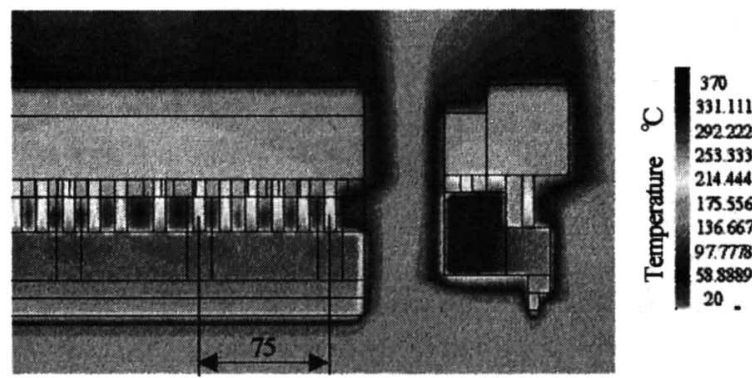

Fig.11 Temperature distribution of heat and flow analysis with 7 heaters instead of 9 heaters

\section{4 ボンディングッール周辺の温度均一性確認}

TCP を液晶基板に本圧着する際, ボンディングッールの加 熱・荷重を受けるために, 液晶基板の下にバックアップツール を設置してある. ボンディングツールの熱が TCP〜ACF〜液晶 基板を伝わって温度が低下するので, バックアップッールにも カートリッジヒータを入れて補助加熱する.

$\mathrm{ACF}$ の接着剤を硬化する温度は, $185^{\circ} \mathrm{C} \pm 5^{\circ} \mathrm{C}$ あ゙ることを第 1 報で述べた. ACF の部分をこの温度にするためには, ボンデ ィングッール先端の温度が $280^{\circ} \mathrm{C}$, バックアップツールの先端 で $60^{\circ} \mathrm{C}$ が必要なことを実験で国んでいる.
バックアップツール単体の温度のばらつきを実験ユニットで 検証した. 図 12 にバックアップッールの構造図を, 図 13 にバ ックアップッール先端の温度を計測した結果を示す. バックア ップツール先端の温度は, 通常の設定温度 $60^{\circ} \mathrm{C}$ のかに, 上下 に $20^{\circ} \mathrm{C}$ 変化させ, その状態の温度のばらつき量も取得した, 各

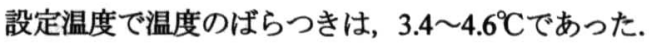

この温度のばらつきが, TCP 本圧着時にどのように影響する かバックアップツールを含めて総合的な熱解析を行った.

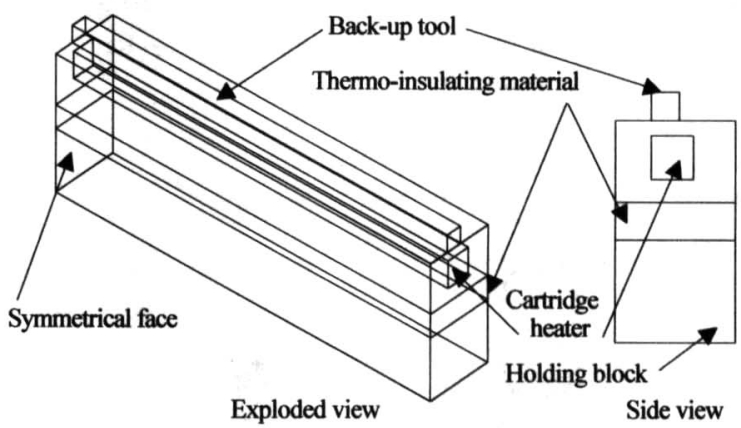

Fig.12 Structure of back-up tool

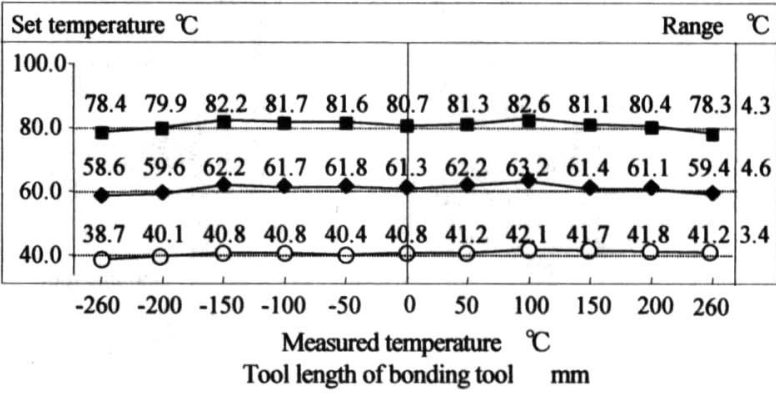

Fig.13 Measured temperatures around the back-up unit

\subsection{T C P 本圧着時の熱・流れ解析モデル}

TCPを本圧着する際の全ての構成部品を解析モデルに入れた. 構成部品は, ボンディングッール, バックアップツール, 液晶 基板・TCP・ACF およびテフロンンシートである. ここでテフ ロンシートの使用目的は, TCP を本圧着する際, ACF の接着剂 がボンディングツールに付着しないようにしたものである.

ACF は厚さが, $0.02 \mathrm{~mm}$, テフロンシートは $0.08 \mathrm{~mm}$ と薄く, この寸法のままでモデル化するのは困難なので, $0.5 \mathrm{~mm}$ に厚く して熱伝導が等価になるように熱伝導率を小さくした. 加熱部 全体の解析モデルを図 14 に示寸. 加熱部全体の熱・流れ解析の 温度分布を図 15 に, 本圧着部周辺の温度分布を図 16 に示す.

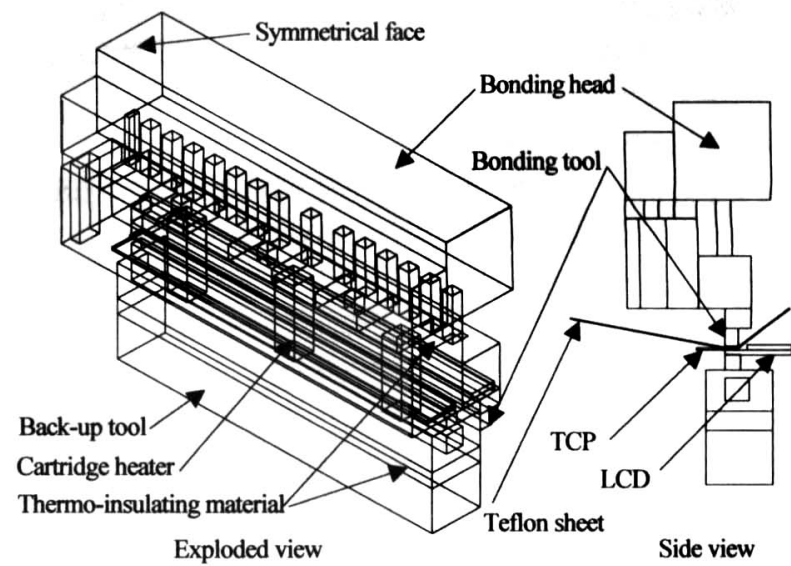

Fig.14 Analytical model of entire heating section heat and flow 


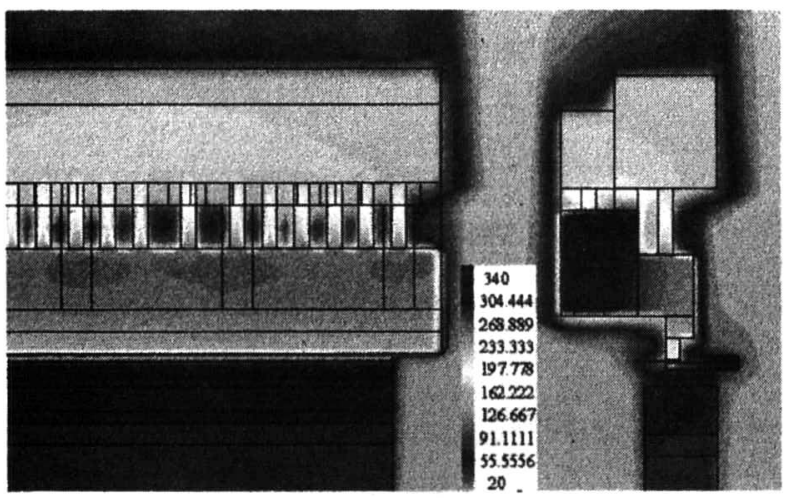

Fig.15 Temperature distribution of entire heating section

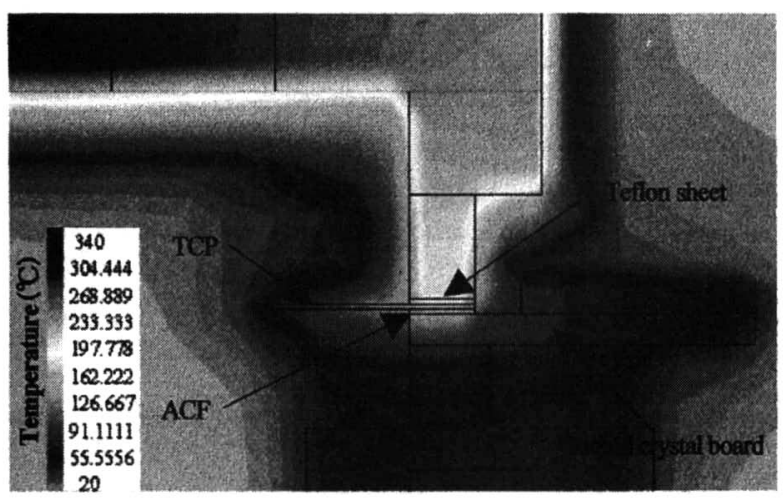

Fig.16 Temperature distribution of finally crimped

$\mathrm{ACF}$ の温度を $185^{\circ} \mathrm{C}$ にするためにカートリッジヒータの温度 を熱・流れ解析したところ, 図 15 と図 16 の解析結果が得られ た.これにより, カートリッジヒータは $340^{\circ} \mathrm{C}$ 設定すれば良 いことが分った.この熱・流れ解析で，各部位の温度観察が可 能となった。 これにより $\mathrm{ACF}$ の接着剂の材質が変わり, 硬化温 度が変った場合でも, 容易にカートリッジヒータの設定温度を 同定できるようになった。

図 16 の温度分布からは, ボンディングツール先端の熱がテフ ロンシート, TCP, ACF, 液晶基板一伝搬していることが分る. さらにボンディングツール先端の熱が伝搬し，TCP 実装部分に 集中していることから, バックアップッールの補助加熱が, 有 効であることが分った.

\section{5 熱・流れ解析の結果}

図 17 にボンディングツール先端の熱·流れ解析と実際に測定 した温度の結果を示す. ボンディングッールは対象なので, 中 心から半分のみを熱・流れ解析した.

熱・流れ解析データと実際に測定したデータは, 両者とも温 度プロファイルは近似しており, 温度差は $1^{\circ} \mathrm{C}$ 以内人ってい た. 図 7 で示した FEMに比較して, 解析精度は $8^{\circ} \mathrm{C}$ から $1^{\circ} \mathrm{C}$ 人 と著しく向上した. また, 放熱フィンを使用しなくても, 従来 のボンディングヘッドと,ほぼ同一の温度ばらつき $4.0^{\circ} \mathrm{C}$ に収め ることができた.

最後にバックアップッールの温度のばらつきが, ボンディン グツールにどのように影響するか考察した. バックアップツー

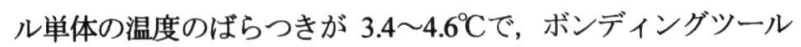
単体のそれは項目 4.3 から $4.0^{\circ} \mathrm{C}$ であった. 図 17 の総合的な温 度のばらつき $4.0^{\circ} \mathrm{C} か ら$, バックアップツールの温度のばらつき が,そのままボンディングヘッドへは影響していない.これは, バックアップツールとボンディングッールで温度差が大きく,
ボンディングツール側が高温で支配的なためと判断した.

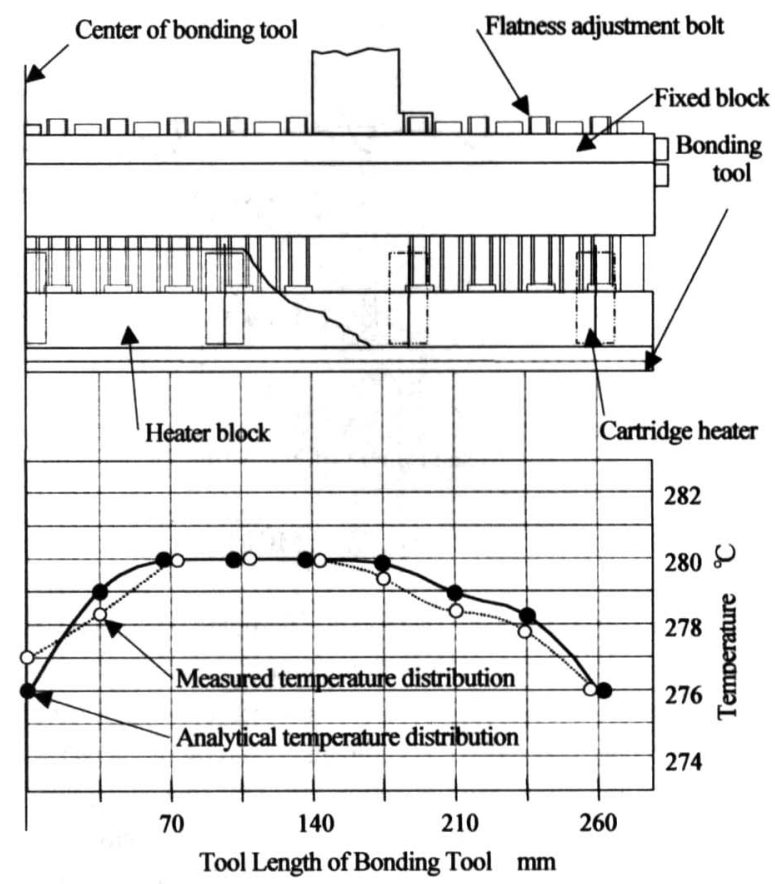

Fig.17 Analytical and measured temperatures around the tip of bonding tool

\section{5. 結 論}

TCP本圧着工程で使用するボンディングツールの温度の均一 化を図るため, 熱解析技術について研究した。

従来, FEM を利用し，熱伝導を中心に解析を行ってきたが, 解析結果と測定データに乘離があった. 今回, FVM を利用し, 熱伝導に加え隣接部品や空気の流れも解析できる熱・流れ解析 を構築した. この解析技術は, 今後さらに大型化する液晶ディ スプレイのボンディングツール開発に適用可能である.

得られた成果を以下に記述する.

(1) FVM と機構開発で, 放熱フィンによる温度の均一化を図る 工程を排除すると同時に放熱フィンそのものを排除した.

(2) 熱・流れ解析によるボンディングツールの熱解析手段を構 築した. 従来の FEM に比較して FVM を適用した熱解析は解析 精度として, 温度のばらつきを $8^{\circ} \mathrm{Cから} 1{ }^{\circ} \mathrm{C}$ 以内とした.これに より, ボンディングツールは, 開発段階で温度の均一性が同定 可能となった.

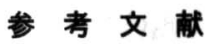

1) 玉井 光一「TCP Outer Lead Bonder for Liquid Crystal Displays」 Technique,ToshibaReview,Vol.48,No2,pp.123-126Japan(1993)

2）玉井 光一液晶ディスプレイ製造装置実用便覧サ仕ンスォーラム (1992)

3) 原田 種真「液晶基板用 T A B - O L B 装置の開発」

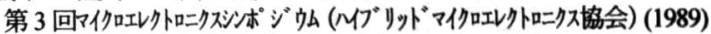
第 1 回ヨーロッパ・アジア メカトロニクス会議 (1996)

4) 玉井光一「High-Accuracy Outer Lead Bonding Technique」 Technique,Toshiba Review,Vol.45,No4,pp.325-328Japan(1990)

5) 高林 弘徳 「Development of high accuracy and high productivity TCP bonding system for LCDs」

6)鈴木 正広「Fully Automated OLB System for LCDs」 Technique,ToshibaReview,Vol.50,No10,pp.787-790Japan(1995)

7) 鈴木 正広「High-Precision and High-Speed Outer Lead Bonding System」Technique,ToshibaReview,Vol.51,No10,pp.63-66Japan(1996)

8) 伝熱工学,日本機械学会, pp.184-185 